\title{
Effect Of Dietary Lipid Level On Growth, Feed Utilization And Body Composition By Nile Perch Juveniles (Lates Niloticus)
}

\author{
Ly Mouhamadou Amadou \\ Universite Cheikh Anta Diop de Dakar, Senegal \\ Universite Gaston Berger de Saint-Louis, Senegal \\ Ba Cheikh Tidiane \\ Universite Cheikh Anta Diop de Dakar, Senegal
}

doi: 10.19044/esj.2016.v12n9p423 $\quad$ URL:http://dx.doi.org/10.19044/esj.2016.v12n9p423

\begin{abstract}
:
The present study was designed to determine the optimum dietary lipid of juveniles Nile perch for better growth performances. Four isonitrogenous (45\%) experimental diets were formulated to contain $9 ; 11$; 13 and $15 \mathrm{~g}$ crude lipid $100 \mathrm{~g}^{-1}$ feed, and fed in triplicate groups of Nile perch (mean weight : $3.28 \pm 0.04 \mathrm{~g}$ ) reared in twelve $50 \mathrm{~L}$ tank for 8 weeks. At the end of the experimental period the group of fish fed $11 \%$ and $9 \%$ lipid, had a significantly higher SGR and body weight gain than the rest of experimental groups. The lowest body weight (13.28 g) was achieved by group of fish fed $15 \%$ lipid. The FCR were significantly lower for fingerling Lates fed diet containing $11 \%$ and $9 \%$ lipid than the rest. The increase of the dietary lipid level in the diet affected significantly the Protein Efficiency Ratio (PER). Body moisture content decreased significantly with the increase of dietary lipid. Body lipid increased significantly with the increase of dietary lipid. Under the experimental conditions applied, the optimum dietary lipid requirement for juvenile Lates niloticus is estimated to be $9.79 \%$.
\end{abstract}

Keywords: Nile perch, Lates niloticus, lipid levels, growth

\section{Introduction:}

The Nile perch, Lates niloticus (Linnaeus 1758), Family centropomidae, is a freshwater carnivorous fish of wide geographical distribution throughout the Ethiopian Region of Africa, occurring commonly in all major river basins including the Nile, Chad, Senegal, Volta and Congo. Most Lates niloticus in their natural environment feed on fish and insects. Moreover, Nile perch is of great social economic importance in the East 
African region (Gumisiriza et al., 2009; Beuving, 2010). The Nile perch fishery is however under threat due to the intensive fishing pressure on the fishery that has resulted in a tremendous decline of its populations (Njiru et al., 2009). Current strategies for increasing Nile perch production point towards the culture of this species (Gregory, 2006). The culture development of this species will depend mainly on the availability of its seed and the development of well balanced and suitable feed. Little information is available on the dietary requirements of Nile perch, and, in particular, there is no information on dietary lipid requirement.

Dietary lipids play an important role as potential supplier of Energy, essential fatty acids and fat soluble vitamins. They also affect the quality of cultured fish because of their influence on the fatty acid composition of body tissues (Guillon et al., 1995). The addition of lipids in fish diets contributes to protein sparing by increasing their digestible energy value (De silva al., 1991).

However, fish are able to utilize dietary lipids up to a certain level, beyond which growth may be retarded owing to reduced feed consumption (Daniels \& Robinson, 1986; Ellis \& Reigh, 1991).

Moreover, a high lipid intake may cause an increase in body lipid deposition and affect carcass quality (Hillestad \& Johnsen, 1994).

The determination of Lates niloticus nutritional requirements is essential for optimizing its aquaculture production. To our knowledge, data concerning the optimal dietary lipid level for Lates niloticus juveniles have not been published. Given this lack of information on the basic nutrient requirements of this species, the present study has been undertaken to conduct experimentation with different lipid level diets from $9 \%$ to $15 \%$ to determine growth performance and body composition of Lates niloticus juveniles.

\section{MATERIALS AND METHODS Experimental conditions}

Wild Juvenile, Lates niloticus, weighing around $3.28 \mathrm{~g}$ at the beginning of the feeding trial were used in this study. These fish were obtained from a local fish dealer at the Diama dam, Saint- Louis, Senegal. Fish were acclimated to the experimental conditions for a period of two weeks. During this period, they were fed with a commercial catfish diet obtained from the National Aquaculture Agency hatchery located in Richard Toll district.

At the beginning of the experiment, fish were bulk-weighed and counted. Each experimental diet was randomly assigned to triplicate with 10 fish (mean weight: $3.28 \pm 0.04 \mathrm{~g}$ ) per glass tank. Water levels in each glass tank were maintained at $50 \mathrm{~L}$ and aerated constantly. 
Experimental diets were hand-fed three times a day at 08: 00; 12: 00 and 17: 00 to apparent satiation, over a 30-min period for 8 weeks.

Fish were subjected to a photoperiod of 12-h dark and 12-h light and all tanks had similar light conditions. Dissolved oxygen levels and water temperature were monitored daily and averaged $7 \mathrm{mg} / \mathrm{l}$ and $30^{\circ} \mathrm{C}$, respectively. Fish were bulk weighed every 2 weeks with fish being starved for $24 \mathrm{~h}$ prior to weight measurements and $12 \mathrm{~h}$ after. All aquaria were cleaned up every day in the morning by scrubbing and siphoning off accumulated waste materials. Each meal after feeding the uneaten food was removed manually to estimate food consumption.

\section{Experimental diets}

Four experimental diets were formulated to contain $9 \% ; 11 \% ; 13 \%$ and $15 \%$ lipid. Fish meal and shrimp meal were used as protein sources, fish oil and soy oil as lipid sources. Fish meal and shrimp meal were finely grounded and poured through a sieve of $425 \mu \mathrm{m}$ mesh. Vitamin and mineral premix were mixed separately with the cellulose and the binder before being added to the main ingredient mixture. Diets were supplemented with fish oil after the addition of water (Table 1). The semi-moist mixture was then pressure pelleted in the food grinder, dried at $35^{\circ} \mathrm{C}$ for two days, cut to desired sizes, packaged into plastic bag and stored frozen until its usage. The diets were screened prior to feeding in order to remove the fines.

Table 1: Formulation of the experimental diets of Nile perch (Lates niloticus).

\begin{tabular}{lcccc}
\hline & \multicolumn{4}{c}{ Diet } \\
\cline { 2 - 5 } Ingredient $(\mathrm{g} / 100 \mathrm{~g})$ & $9 \%$ & $11 \%$ & $13 \%$ & $15 \%$ \\
\hline Fish meal & 52 & 53 & 53 & 53 \\
Shrimp meal & 27 & 27 & 27 & 27 \\
Corn meal & 15 & 12 & 10 & 8 \\
Fish oil : soy oil (7:3) & 2 & 4 & 6 & 8 \\
Vit mix $^{\mathrm{a}}$ & 2 & 2 & 2 & 2 \\
Min mix $^{\mathrm{b}}$ & 2 & 2 & 2 & 2 \\
Total & 100 & 100 & 100 & 100 \\
\hline
\end{tabular}

${ }^{a}$ Vitamin mixture (mg or IU. $\mathrm{Kg}^{-1}$ ): Biotin, 0.25 ; folic acid, 0.75 ; choline chloride, 250 ; ascorbic acid, 50; vitamin B12, 0.05; vitamin K3 : 100 .

${ }^{\mathrm{b}}$ Mineral mixture (mg/Kg mixture): Ca, $0.3 \mathrm{~g} ; \mathrm{Fe}, 2 \mathrm{~g}$; CoCl2, 0.01g; Zn, $1.32 \mathrm{~g}$; Se, 0.019g; $\mathrm{CuCl} 2,0.1 \mathrm{~g} ; \mathrm{Na}, 0.34 \mathrm{~g} ; \mathrm{Mn}, 1.8 \mathrm{~g}$.

\section{Sampling and analytical methods}

At the beginning of the feeding trial, 10 fish were randomly sampled from the initial fish and at the end of the 8-week experiment 3 fish from each tank were sampled and all the sample are freeze-dried for subsequent proximate analyses. 
The experimental diets and samples of the fish carcasses were analyzed for proximate composition according to the Association of Official Analytical Chemists: AOAC (1984) procedures. Crude lipid was determined by the ether extraction method by Soxtec System HT (Soxtec System HT6; Tecator); crude protein was determined with a Kjeltec system 1002 (Tecator); crude fiber was determined by the Fibertec system M 1020 hot extractor (FOSS Tecator); crude ash by incineration in a muffle furnace at $550^{\circ} \mathrm{C}$ for $24 \mathrm{~h}$, and dry matter by drying in an oven at $105^{\circ} \mathrm{C}$ for $24 \mathrm{~h}$;

Several parameters were routinely monitored to ensure good water quality maintained. Water temperature and dissolved oxygen was measured everyday using YSI Model 58 oxygen meter (Yellow Springs Instrument, Yellow Springs, OH, USA). Water $\mathrm{pH}$ was measured everyday by $\mathrm{pH}$ tester DMT-30 Series.

\section{Calculations and Statistical Analysis}

Growth response parameters were calculated as follows: Weight gain $(\%)=100^{*}$ ( (final mean body weight - initial mean body weight $) /$ initial mean body weight); Specific Growth Rate (SGR, \% /day) $=100 *((\mathrm{In} \mathrm{Wt}-\mathrm{In}$ $\mathrm{Wi}$ / /T), where $\mathrm{Wt}$ is the weight of fish at time t, Wi is the weight of fish at time 0 and $\mathrm{T}$ is the rearing period in days; Feed Conversion Rate $(\mathrm{FCR})=$ total dry feed fed g/ fish / total wet weight gain g/ fish. Survival rate $(\%)=$ $100^{*}$ (number of fish which survived/initial number of fish). Protein efficiency ratio (PER) was calculated using the following formula: wet weight gain (g)/protein intake (g). The optimum lipid required was estimated by taking the first derivative of $\mathrm{Y}$ on the polynomial regression model with respect to the relevant X.

Results are presented as mean \pm SEM. Data were subjected to oneway analysis of variance (ANOVA) to test the effect of four dietary lipid levels as main effect. Treatment effects were considered significant at $p$ $\leqq 0.05$; Duncan's new multiple range tests was used to compare significant difference among treatments. The survival data were transformed into a normal distribution using the arcsine square root prior to analysis of variance. All statistical analysis was carried out using the SAS/PC statistical software.

\section{RESULTS}

During the experiment water temperature monitored ranged from 29 to $30^{\circ} \mathrm{C}$; dissolved oxygen was $6.5 \pm 0.5 \mathrm{mg} / \mathrm{L}$ and $\mathrm{pH}$ ranged from 7.5 to 8 . All parameters are considered to be suitable for fish growth and survival. Survival was similar $(p>0.05)$ among dietary treatments and ranged from $86.67 \pm 0.06 \%$ to $76.67 \pm 0.07 \%$ over the eight-week trial (Table 3). The effects of dietary lipid levels on weight gain, specific growth rate, feed 
intake, feed conversion ratio and protein efficiency ratio of Lates fingerlings fed the experimental diets are presented in Table 3.

Table 2: Proximate analysis of the experimental diets of Nile perch (Lates niloticus).

\begin{tabular}{lcccc}
\hline Chemical analysis & $9 \%$ & $11 \%$ & $13 \%$ & $15 \%$ \\
\hline Moisture & 6,7 & 6,8 & 6,6 & 6,6 \\
Crude protein & 45,83 & 45,94 & 45,81 & 45,73 \\
Crude fat & 9,13 & 11,1 & 13 & 15,2 \\
Crude fiber & 2,8 & 2,7 & 2,6 & 2,6 \\
Crude ash & 10,9 & 10,8 & 10,8 & 10,7 \\
NFE & 19,4 & 17 & 15 & 13,6 \\
Gross Energy (kcal/100gm) & 458,99 & 469,37 & 483,66 & 490,59 \\
P/E Ratio & 109,15 & 107,59 & 103,99 & 102,32 \\
\hline
\end{tabular}

Average body weight (g) of juveniles Lates fed experimental diets at the start did not differ, indicating that groups were homogenous. At the end of the experimental period the group of fish fed $11 \%$ and $9 \%$ lipid, had a significantly ( $p \leqq 0.05$ ) higher SGR and body weight gain than the rest of experimental groups. The lowest body weight (13.28 g) was achieved by group of fish fed lipid level $15 \%$. However, SGR were 2.77, 2.82, 2.63 and 2.48 for groups of fish fed on diet containing 9, 11, 13 and $15 \%$ lipids, respectively.

Table 3: Growth performance, and survival of Lates niloticus fed the experimental diets.

Values are means \pm standard deviation $(n=3)$. Within a row, means with different superscript letters differ significantly $(p \leqq 0.05)$.

\begin{tabular}{|c|c|c|c|c|}
\hline \multirow[b]{2}{*}{ Parameters } & \multicolumn{4}{|c|}{ Diet } \\
\hline & $9 \%$ & $11 \%$ & $13 \%$ & $15 \%$ \\
\hline Initial body weight (g) & $3.27 \pm 0.22$ & $3.28 \pm 0.05$ & $3.26 \pm 0.05$ & $3.30 \pm 0.03$ \\
\hline Final body weight (g) & $15.43 \pm 0.46^{\mathrm{a}}$ & $15.89 \pm 0.56^{\mathrm{a}}$ & $14.22 \pm 0.11^{\mathrm{b}}$ & $13.28 \pm 0.47^{\mathrm{c}}$ \\
\hline Weight gain $(\%)$ & $372.20 \pm 11.24^{\mathrm{a}}$ & $385.06 \pm 23.82^{\mathrm{a}}$ & $336.22 \pm 3.17^{\mathrm{b}}$ & $302.23 \pm 17.99^{c}$ \\
\hline $\operatorname{SGR}(\%)$ & $2.77 \pm 0.04^{\mathrm{a}}$ & $2.82 \pm 0.09^{\mathrm{a}}$ & $2.63 \pm 0.01^{\mathrm{b}}$ & $2.48 \pm 0.08^{c}$ \\
\hline Feed intake & $24.26 \pm 0.51^{\mathrm{a}}$ & $24.3 \pm 0.44^{\mathrm{a}}$ & $22.93 \pm 0.50^{\mathrm{ab}}$ & $22.93 \pm 0.50^{\mathrm{b}}$ \\
\hline Feed conversion ratio & $1.99 \pm 0.05^{\mathrm{b}}$ & $1.93 \pm 0.07^{\mathrm{b}}$ & $2.09 \pm 0.06^{\mathrm{ab}}$ & $2.26 \pm 0.24^{\mathrm{a}}$ \\
\hline Protein efficiency ratio & $1.11 \pm 0.03^{\mathrm{a}}$ & $1.15 \pm 0.04^{\mathrm{a}}$ & $1.06 \pm 0.03^{\mathrm{ab}}$ & $0.99 \pm 0.10^{\mathrm{b}}$ \\
\hline Survival rate $(\%)$ & $83.33 \pm 0.15$ & $76.67 \pm 0.06$ & $83.33 \pm 0.06$ & $86.67 \pm 0.06$ \\
\hline
\end{tabular}

The FCR were significantly lower ( $p \leqq 0.05$ ) for fingerling Lates fed a diet containing $11 \%$ and $9 \%$ lipid than the rest of experimental groups. The highest FCR (2.26) was achieved by group of fish fed $15 \%$ lipid level.

The increase of the dietary lipid level in the diet affected significantly the Protein Efficiency Ratio (PER) ( $p \leqq 0.05$ ). PER increased with the dietary lipid level up to $11 \%$ and decreased later on. The lowest PER was found with the diet with $15 \%$ of lipid (Table 2). PER in $9 \%$ and $11 \%$ lipid diet was 
higher than PER in 15\% lipid diet. However, there was no difference in PER among $9 \%, 11 \%$ and $13 \%$ lipid diet and also between $13 \%$ and $15 \%$ lipid diet (Table 3).

Table 4: Body composition (on wet weight basis) of Nile perch fingerlings fed the experimental diets. Values are means \pm standard deviation $(n=3)$. Within a row, means with different superscript letters differ significantly $(p \leqq 0.05)$.

Parameters Lipid level (\%)

\begin{tabular}{lcccc} 
& 9 & 11 & 13 & 15 \\
\hline Moisture & $80.61 \pm 0.12^{\mathrm{a}}$ & $79.28 \pm 0.18^{\mathrm{b}}$ & $78.46 \pm 0.33^{\mathrm{c}}$ & $77.51 \pm 0.15^{\mathrm{d}}$ \\
Protein & $52.33 \pm 0.21$ & $52.47 \pm 0.23$ & $52.33 \pm 0.21$ & $52.3 \pm 0.1$ \\
Lipid & $11.73 \pm 0.15^{\mathrm{d}}$ & $12.43 \pm 0.21^{\mathrm{c}}$ & $12.96 \pm 0.09^{\mathrm{b}}$ & $13.84 \pm 0.14^{\mathrm{a}}$ \\
Ash & $20.43 \pm 0.09$ & $20.25 \pm 0.06$ & $20.74 \pm 0.1$ & $20.21 \pm 0.09$ \\
\hline
\end{tabular}

The effect of dietary lipid levels on body composition is presented in table 4. Body moisture content decreased significantly with the increase of dietary lipid. Body lipid increased significantly with the increase of dietary lipid $(p \leqq 0.05)$. Body protein and ash content was not affected by the dietary treatments $(p>0.05)$.

When the second-order regression was employed, based on specific weight gain for estimating the dietary lipid requirement of $L$. niloticus (Fig. 1), the regression equation was as follows: $Y=-0.0121 x^{2}+0.2369 x+1.6301$. The optimum dietary lipid requirement for juvenile Lates is estimated to be $9.79 \%$.

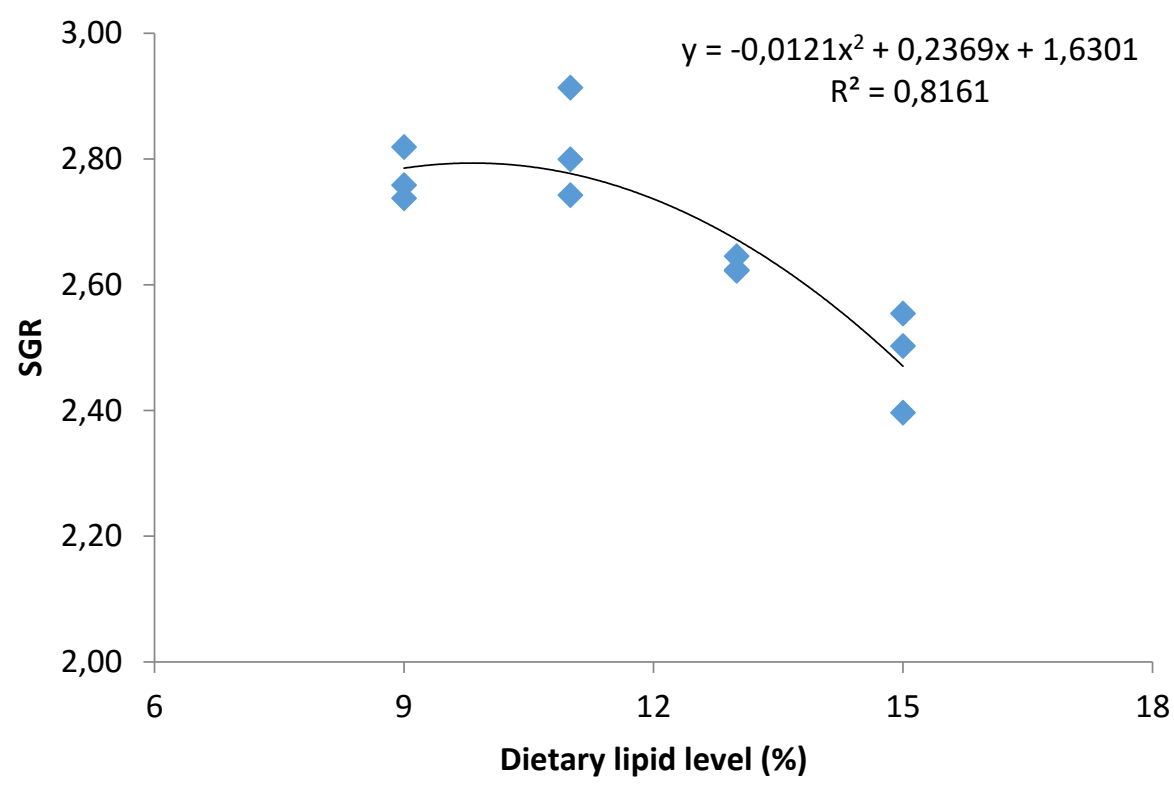

Figure 1: Second order regression of SGR on dietary lipid level for L. niloticus. 


\section{DISCUSSION}

During the experiment water temperature monitored ranged from 29 to $30^{\circ} \mathrm{C}$; dissolved oxygen was $6.5 \pm 0.5 \mathrm{mg} / \mathrm{L}$ and $\mathrm{pH}$ ranged from 7.5 to 8 . All parameters are considered to be suitable for fish growth and survival.

The present study is the first report to our knowledge regarding dietary lipid needs of Nile perch during their juvenile stage. It is well known that Dietary lipids are an important source of energy that also provide essential fatty acids, phospholipids, sterols and fat-soluble vitamins necessary for proper functioning of physiological processes and maintenance of biological structure and function of cell membranes (Sargent et al., 1989). They also affect the quality of cultured fish because of their influence on the fatty acid composition of body tissues (Guillon et al., 1995).

The establishment of the dietary lipid level for optimal growth performance and body composition of juvenile Nile perch is a contribution towards the development of specific feeds for on-growing Nile perch.

Generally, the increase of dietary lipid level improves growth, feed and protein efficiency, as it spares proteins that could otherwise have been catabolized and used as an energy source (De Silva et al., 2001). However, the excessive supplement of dietary lipid could destroy growth and health of fish owing to the abnormal lipid deposition in fish body (Lee \& Kim, 2005; Wang et al., 2006). In addition fish have an optimum level of dietary lipids over which dietary fat can cause growth depression (Daniels \& Robinson, 1986; Pei et al., 2004). This observation was confirmed in the present study in which the optimum dietary lipid is estimated to be $9.79 \%$. The growth reduction at high lipid levels could be due to the limited ability to digest and absorb high amounts of lipid or a reduction in feed intake.

The results of this study showed that, PER increased with the dietary lipid level up to $11 \%$ and decreased later on; WG tended to decrease, but FCR tended to increase, with increasing the dietary lipid level from 11 to $15 \%$. These results indicate that elevating the dietary lipid level from $11 \%$ to $15 \%$ could not induce protein-sparing effect in Nile perch. Similarly, no protein-sparing effects of excessive dietary lipid in other fish species were observed in Pseudobagrus ussuriensis Fingerlings (Wang et al., 2013); Lates calcarifer juveniles (Catacutan \& Coloso, 1995); and Paralichthys olivaceus juveniles (Lee \& Kim, 2005).

In contrast, a protein-sparing effect of lipid has previously been documented in channel catfish (Page \& Andrews, 1973) and Japanese seabass Lateolabrax japonicus (Ai et al., 2004). Thus, it is important to provide an appropriate ratio of protein and non-protein energies for the formulation of cost-effective and environment friendly fish feed. 
Chemical analysis at the end of the experiment is frequently used to determine the influence of feed on fish composition. Both environment and diet are exogenous factors that affect the proximate composition of cultured fish. It should be noted that, the composition of the feed is the only factor, which could have influenced the difference chemical composition of fish, as other endogenous factors were maintained uniform during the study work.

Data on the body composition content of fish allows assessing the efficiency of transfer of nutrients from feed to fish and also helps predict the overall nutritional status.

The results of the present study indicated that the dietary lipid level significantly affected the body composition of fish. . Body moisture content decreased significantly with the increase of dietary lipid. Body protein and ash content in Nile perch was not affected by the dietary treatments.

A significant increase in body fat deposition was noticed with increase in dietary lipid level, this is consistent with others previously findings for African catfish (Ali \& Jauncey, 2005), black catfish (Salhi et al., 2004), cobia Rachycentron canadum (Craig et al., 2006); red drum (Ellis \& Reigh, 1991; Serrano et al., 1992); and grey mullet (Rangaswamy et al., 1998). In addition, flounder (Lee \& Kim, 2005), largemouth bass Micropterus salmoides (Bright et al., 2005), cuneate drum (Wang et al., 2006) and blackspot seabream (Figueiredo-Silva et al., 2010), exhibited significantly increased body lipid content when fed at high dietary lipid levels.

The survival rate of L. niloticus juveniles under different treatments ranged from 76 to $86 \%$ over the eight-week trial. The survival was not significantly affected by the dietary lipid level. On the contrary, in some species, differences were observed in the survival rate due to the different dietary lipid levels, such as in juveniles Kutum (Ebrahimi \& Ouraji, 2011); darkbarbel catfish (Zheng et al., 2010)

\section{Conclusion:}

In conclusion, data from the present study indicate that the optimum dietary lipid requirement for juvenile Lates niloticus is estimated to be $9.79 \%$ to maintain a good overall growth performance.

\section{References:}

AOAC (Association of Official Analysis Chemists), 1984. Official Methods of Analysis, 14th edition, AOAC Arlington, VA, 1141pp.

Ai QH, Mai KS, Li HT, 2004. Effects of dietary protein to energy ratios on growth and body composition of juvenile Japanese seabass, Lateolabrax japonicas. Aquaculture 230: 507-516. 
Ali MZ. and Jauncey K, 2005. Approaches to optimizing dietary protein to energy ratio for African catfish Clarias gariepinus (Burchell, 1822). Aquacult. Nutr 11: 95-101.

Beuving JJ, 2010. Playing pool along the shore of Lake Victoria: Fishermen, careers, and capital accumulation in the Ugandan Nile perch business. Africa 80(2): 224-248.

Bright LA, Coyle SD, Tidwell JH, 2005. Effect of dietary lipid level and protein energy ratio on growth and body composition of largemouth bass Micropterus salmoides. J. World Aquac. Soc 36: 129-134.

Catacutan MR. and Coloso RM, 1995. Effect of dietary protein to energy ratios on growth, survival, and body composition of juvenile Asian seabass, Lates calcarifer. Aquaculture 131: 125-133.

Craig SR, Schwarz MH, McLean E, 2006. Juvenile cobia (Rachycentron canadum) can utilize a wide range of protein and lipid levels without impacts on production characteristics. Aquaculture 261: 384-391.

Daniels WH. and Robinson EH, 1986. Protein and energy requirements of juvenile red drum (Sciaenops ocellatus). Aquaculture 53: 243-252.

De Silva SS, Gunasekera RM, Shim KF, 1991. Interactions of varying dietary protein and lipid levels in young red tilapia: evidence of protein sparing. Aquaculture 95: 305-318.

De Silva SS, Gunasekera RM, Gooley G, Ingram BA, 2001. Growth of Australian shorfin eel (Anguilla australis) elvers given different dietary protein and lipid levels. Aquaculture Nutrition 7: 53-57.

Ebrahimi G. and Ouraji H, 2011. Dietary lipid requirement for the Kutum fingerlings, Rutilus frisii kutum (Kamenskii 1901). Research journal of Animal Sciences 5(1): 1-5.

Ellis SC. and Reigh RC, 1991. Effects of dietary lipid and carbohydrate levels on growth and body composition of juvenile red drum, Sciaenops ocellatus. Aquaculture 97: 383-394.

Figueiredo-Silva AC, Corraze G, Borges P, Valente LMP, 2010. Dietary protein/lipid level and protein source effects on growth, tissue composition and lipid metabolism of blackspot seabream (Pagellus bogaraveo). Aquacult. Nutr 16: 173-187.

Gregory RG, 2006. The Nile perch Lates niloticus: a potential candidate for cage aquaculture. In J. F. Halwart, FAO Regional Technical expert workshop on cage culture in Africa, Entebbe Uganda, 20th to 23rd October 2004. FAO Fisheries proceedings (Vol. No. 6).

Guillon A, Soucy P, Khalil M, Adambounou L, 1995. Effect of dietary vegetable and marine lipid on growth, muscle, fatty acid composition and organoleptic quality of flesh of brook charr (Salvelinus fontinalis). Aquaculture 136: 351-362. 
Gumisiriza R, Mshandete AM, Rubindamayugi MS, Kansiime F, Kivaisi AK, 2009. Nile perch fish processing waste along Lake Victoria in East Africa: Auditing and characterization. Afr. J. Environ. Sci. Technol 3(1): 013-020.

Lee SM. and Kim KD, 2005. Effect of various levels of lipid exchanged with dextrin at different protein level in diet on growth and body composition of juvenile flounder Paralichthys olivaceus. Aquacult. Nutr 11: 435-442.

Njiru M, Getabu A, Taabu AM, Mlaponi E, Muhoozi L, Mkumbo OC, 2009. Managing Nile perch using slot size: is it possible? Afr. J. Trop. Hydrobiol. Fish 12: 9-14.

Page JW, Andrews JW, 1973. Interaction of dietary levels of protein and energy on channel catfish (Ictalurus punctatus). The Journal of Nutrition 103: 1339-1346.

Pei Z, Xie S, Lei W, Zhu X, Yang Y, 2004. Comparative study on the effect of dietary lipids level on growth and feed utilization for gibel carp (Carassius auratus gibelio) and Chinese longsnout catfish (Leiocassis longirostris Gunther). Aquaculture Nutrition 10: 209-216.

Rangaswamy CP, Gopal C, Swamy DN, 1998. Effect of varying dietary lipid levels on the growth and body composition of fingerlings of the grey mullet Liza macrolepis (Smith). Indian J. Fish 45(2): 157-161.

Salhi M, Bessonart M, Chediak G, Bellagamba M, Carnevia D, 2004. Growth, feed utilization and body composition of black catfish, Rhamdia quelen fry fed diets containing different protein and energy levels. Aquaculture 231: 435-444.

Sargent J, Henderson RJ, Tocher DR, 1989. The lipids. In: Fish Nutrition. J. E. Halver (Ed.), Academic Press, Inc. New York: 153-218.

Serrano JA, Nematipour GR, Gatlin DM, 1992. Dietary protein requirement of the red drum (Sciaenops ocellatus) and relative use of dietary carbohydrate and lipid. Aquaculture 101: 283-291.

Shearer KD, 1994. Factors affecting the proximate composition of cultured fishes with emphasis on salmonids. Aquaculture 119: 63-88.

Wang F, Han H, Wang Y, Ma X, 2013. Growth, feed utilization and body composition of juvenile golden pompano Trachinotus ovatus fed at different dietary protein and lipid levels. Aquaculture nutrition $19: 360-367$.

Wang Y, Guo JL, Li K, Bureau DP, 2006. Effects of dietary protein and energy levels on growth, feed utilization and body composition of cuneate drum (Nibea miichthioides). Aquaculture 252: 421-428.

Zheng K, Zhu X, Han D, Yang Y, Lei W, Xie S, 2010. Effects of dietary lipid levels on growth, survival and lipid metabolism during early ontogeny of Pelteobagrus vachelli larvae. Aquaculture 299: 121-127. 